\title{
STANDING TO SUE IN COPYRIGHT INFRINGEMENT SUITS $\dagger$
}

Suits for the infringement of a copyright are allowed by Section 101 of Title 17 of the United States Code, which provides that one who infringes the copyright in any protected work shall be liable to "pay to the copyright proprietor" damages. Section 112 allows "any party aggrieved" to file for an injunction to prevent and restrain the violation of any right secured by the Copyright Act. 1 This section, however, has been narrowly interpreted so as to require a party to the suit to be the "copyright proprietor."2 Thus, the statute gives only "copyright proprietors" the right to sue for infringement. Therefore, the statutory problem faced by the cases involving standing to sue for infringement is whether the particular plaintiff is the "copyright proprietor." Two underlying threads seem to run through almost all the cases in this area. The courts have tried to allow one who has a legitimate interest in the copyright to obtain redress from a wrongdoer; yet they have also sought to prevent a defendant from being harassed by a multiplicity of suits. The balance of these two considerations has shifted and their reconciliation has been difficult.

In order to examine this problem more fully, cases involving standing to sue in infringement suits have been divided into two broad categories: (I) cases where the copyright owner has licensed one or several methods of exploitation, and (II) cases where the copyright has been transferred and only a royalty interest retained.

The statutory monopoly obtained by the owner of a copyright is one that is legally indivisible. ${ }^{3}$ This means that an author or composer may obtain a copyright for his work which will protect him against its republication without his authorization and against its use for translation, dramatization, or the making of a motion picture film; but if he desires to transfer to another any one of these exclusive rights he cannot sell such right directly so as to confer upon his

† This comment was submitted for the Nathan Burkan Memorial Competition at the University of Chicago Law School and is published through the courtesy of the American Society of Composers, Authors and Publishers.-Ed.

117 U.S.C. $\$ 112$ (1958).

2 Goldwyn Pictures Corp. v. Howells Sales Co., 282 Fed. 9 (2d Cir. 1922).

3 In Hirshon v. United Artists Corp., 243 F.2d 640, 643 (1957), the court quoted with approval the statement that, the copyright proprietor "may transfer the legal title to his copyright only in totality; the copyright may not be split up and partially assigned as to the various rights encompassed therein." Accord, Machaty v. Astra Pictures Inc., 197 F.2d 138 (2d Cir. 1952), cert. denied, 344 U.S. 827 (1953). 
purchaser the right to sue for any infringement. ${ }^{4}$ Although "legally" indivisible, copyrights are in fact divided through sales of separate rights. In practice, most transactions involving copyrights do not transfer the entire copyright title. If the business world treated copyrights as indivisible, many problems of standing to sue would not arise. This is because it is clear that the assignee of the entire copyright title may sue in his own name. 5

As a result of the divergence between the legal theory of indivisibility and the everyday splintering transactions of the business world, standing to sue in infringement cases has become an increasingly difficult problem. The problem, however, cannot be looked at solely as one of divisibility or nondivisibility since the courts have not uniformly denied protection to the purchaser of less than the entire copyright. ${ }^{6}$ The tendency of the courts has been in the direction of fuller protection for the purchaser of separate rights. Within a framework of nondivisibility the courts have protected the purchaser of less than the entire copyright by allowing him to sue if the copyright proprietor joined with him in the suit. 7 This limited protection was derived by analogy to the landmark patent case of Waterman $v$. McKenzie, 8 but is generally limited to an exclusive licensee. 9 The Supreme Court in Waterman had decided that the transfer there at issue was a mere license and therefore did not give the licensee the right to sue alone. Consequently, in the Goldwyn case a copyright owner who transferred less than the entire copyright was considered as merely granting a license so that his transferee could not sue alone.10 After Goldwyn the next step was to allow the exclusive licensee, who did in fact join the copyright owner, to protect his limited right.11

The formalism of the early rules gradually came to be supplanted by an "interest" approach. Courts became less preoccupied with whether a particular transfer was an assignment or a license 12 and more occupied with the

4 This situation has engendered a considerable amount of critical comment. See, e.g., Ladas, International Protection of Literary and Artistic Property 795 (1938). In 1927 a bill which would have provided for the legal divisibility of the copyright title was introduced in the House of Representatives (H.R. 16808, 69th Cong., 2d Sess.), but it was never enacted into law.

5 Amdur, Copyrught law and Practice 913 (1936).

6 See, e.g., Ted Browne Music Co. v. Fowler 290 Fed. 751 (2d Cir. 1923).

7 See, e.g., Buck v. Elm Lodge, 83 F.2d 201 (2d Cir. 1936).

8138 U.S. 252 (1890). See, e.g., Buck v. Elm Lodge, 83 F.2d 201 (2d Cir. 1936).

9 An exclusive licensee is one who is granted by the copyright proprietor permission to exercise one or more, but not all, of the rights in a copyright, and is assured by the proprietor that no one else shall be allowed to exercise the same rights.

to Goldwyn Pictures Corp. v. Howells Sales Co., 282 Fed. 9 (2d Cir. 1922).

" See, e.g., Buck v. Elm Lodge, 83 F.2d 201 (2d Cir. 1936).

12 The question of whether a particular transfer is an assignment or a license is a highly technical problem that has created a great deal of confusion. See U.S. COPYRIGHT OFFICE, DivisibILITY OF COPYRIGHTS 13-16 (1958). 
question whether the particular plaintiff in the case before them had an interest sufficient to warrant protection. Under this analysis it was not unexpected that the exclusive licensee of less than the entire copyright was the first transferee protected, since no one else could legitimately be granted the rights that had been granted to him. A recent example of a recognition of the substantial interest in an exclusive licensee is provided by Lacquer Mfg. Corp. v. Maas, ${ }^{13}$ where an exclusive licensee was allowed to sue in his own name. The theory of the court was that the exclusive licensee was the "substantial" owner of the patent, and therefore he had the implied right to sue alone.

The evolution of an overall interest approach to standing to sue problems in copyright law can be said to have begun with Tully v. Triangle Film Corp. ${ }^{14}$ In Tully the plaintiff was a copyright owner who had transferred the stage rights to a third party, while reserving to himself the motion picture rights. The defendant in Tully had allegedly infringed plaintiff's copyright through the production of a motion picture. In the resulting infringement suit Tully joined the assignee of the stage rights, whereupon the defendant moved to dismiss on the grounds of misjoinder. The court agreed with the defendant and held that, with respect to the presentation by motion picture, the assignee of the stage rights had no interest which the court would protect and therefore the complaint was dismissed with leave to amend. The assignee of the stage rights could not "complain, because [the production of a competing motion picture] was one of the probabilities to be contemplated when Tully reserved the motion picture rights." 15

The court in Tully regarded as irrelevant a suggestion that the motion picture presentation of the copyrighted work would be financially injurious to the assignee of the stage rights. Consequently, later courts in ascertaining whether the particular plaintiff before it had a "legitimate interest" have not regarded financial injury as conclusive.16 However, financial injury has recently been given great weight in determining what amounts to a legitimate interest. In Peter Pan Fabrics Co. v. Acadia Co.,17 decided in 1959, economic realities seemed to govern the court's decision. Although the plaintiff was the copyright proprietor, in its suit to enjoin an alleged infringement of its copyrighted design the plaintiff company joined its corporate parent. Because of the extensive economic activities engaged in by the parent with regard to the design its joinder represented "justifiable caution, inasmuch as ... the ultimate proofs [may] establish that Glass [the corporate parent] is the 'real party in interest.' Moreover ... Glass's relation to the copyrights [may show] an 'equitable interest'...."."18

13111 F. Supp. 139 (D.N.J. 1953).

14229 Fed. 297 (S.D.N.Y. 1916).

15 Id. at 299.

${ }^{16}$ See Field v. True Comics, 89 F. Supp. 611 (S.D.N.Y. 1950).

17173 F. Supp. 292 (S.D.N.Y. 1959), aff'd, 274 F.2d 487 (2d Cir. 1960).

18 Id. at 297. 
Although the copyright proprietor of record is the legal title holder, ${ }^{19}$ the court in Peter Pan was not the first to question whether the record proprietor had actually retained a sufficient "interest" to give him standing to sue. In Greenbie v. Noble,20 an author of a book copyrighted in her name was allowed to sue an infringing publisher because she had retained the right to make another version of her novel. Without this retained interest the court implied that she could not have maintained the suit since all publication rights had been transferred to a publisher. The court here was clearly looking at the standing to sue problem as a question of who was injured rather than as one of classification. In Eliot v. Geare Marston, Inc.21 standing to sue also turned on whether the plaintiff was actually injured. Although the plaintiff had been assigned all the rights in the copyright except the serial rights in America, she could not sue an infringer who had published her article in serial form. The court asked itself who was damaged and determined that since the plaintiff did not have the serial rights she had no interest in protecting against their infringement. The copyright proprietor-publisher was considered the only one entitled to damages.

The approach used in Eliot and Greenbie may be contrasted with that used in New Fiction Publishing Co.v. Star Co.22 In New Fiction the plaintiff was the transferee of the "serial rights," which were understood to comprehend all publishing rights including magazine and newspaper publishing rights with the exception of book, dramatic and scenario rights. The defendants had allegedly infringed by publishing the work in their newspaper. The court stated that the sole question was whether the plaintiff was the assignee of or merely the licensee under a copyright. The court carefully pointed out that it was not passing on the question which would be presented if the proprietor were made a party plaintiff, and held that since the transferee was merely a licensee it had no standing to sue. 23 The manifest reason for the decision was the court's fear that if the plaintiff were allowed to recover, every other licensee of the copyright could sue the defendant, and each obtain a separate judgment for the same violation. Under an interest approach this fear would not be controlling as other licensees could not show the requisite "interest," since the instant

19 Harms v. Stern, 229 Fed. 42 (2d Cir. 1915) (legal title is in the one who takes out the copyright); Ball, THe LaW of Copyright and LITERARY PROPERTY 475 (1944).

20151 F. Supp. 45 (S.D.N.Y. 1957). See Machaty v. Astra Pictures, 197 F.2d 138 (2d Cir. 1952), cert. denied, 344 U.S. 827 (1953), where the court, apparently suspecting some type of misconduct on the licensee's part, prevented an assignee of a copyright, who was the record owner, from suing without showing continuation of its license or joinder of its licensor as a party to the suit.

2130 F. Supp. 301 (E.D. Penn. 1939).

22220 Fed. 994 (S.D.N.Y. 1915).

23 In doing so the court summarily rejected the plaintiff's argument that, if the owner of such rights as the plaintiff had could not sue, a valuable economic opportunity will be lost to the author as the result of the diminished protection of his transferee. Modern courts have treated this argument with a good deal more respect. 
plaintiff was the exclusive licensee of the newspaper publishing rights at the time of the infringement which violated those rights.

An unequivocal adoption of an interest approach to standing to sue questions in infringement suits may have been foretold by the recent decision in Schwartz v. Broadcast Music, Inc. ${ }^{24}$ The Schwartz case was a private antitrust suit brought against Broadcast Music, Inc., by certain composer and author members of the American Society of Composers, Authors and Publishers (ASCAP). The plaintiffs alleged that the defendant was seeking to fix the price at which the plaintiff's' music would be bought. The defendant moved for summary judgment based on plaintiff' lack of standing to sue. The issue faced by the court was whether the alleged antitrust conduct had injured the plaintiffs in their business or property within the meaning of the antitrust statutes so as to give them standing to sue. The test applied by the court was that people "harmed only incidentally by antitrust violations have no standing to sue ... only those at whom the violation is directly aimed, or who have been directly harmed [can sue]." 25 The defendant claimed that the plaintiffs had no standing because their conspiracy, if it injured anyone, injured ASCAP and the injury to plaintiff was remote. The court held that as far as the fixing of the price for public performance of the plaintiffs' songs, the plaintiffs had no standing to sue since ASCAP had the exclusive right to license the public performance of the plaintiffs' songs. The fact that the plaintiffs would receive reduced royalties was considered only an indirect injury. ASCAP's pooling of all license fees received and its complete control over the distribution of the fees would tend to support this conclusion. The court, however, did not completely close the door to judicial relief as they saw'no reason why ASCAP could not be brought into the present action or be allowed to sue in its own name.

A second aspect of the Schwartz case was the plaintiffs' charge that the defendant was inducing publishers not to promote the plaintiff' compositions. The defendant argued that the plaintiffs had no standing to sue, because the plaintiffs had transferred the publishing and recording rights as well as the right to secure a copyright to their individual publishers. The court, however, held that this part of the conspiracy was directed against the plaintiffs and not the publishers. The publishers were not "in fact" damaged because they received payments from the defendant for not promoting the plaintiffs' compositions. The mere fact of the plaintiffs divesting themselves of publishing and recording rights did not deprive them of standing to sue. In both aspects of the Schwartz case the court looked to see who in fact was directly injured. The court did not trifle with the technical point of who was the legal title holder of the copyright. Standing to sue, therefore, turned on substance rather than

24180 F. Supp. 322 (S.D.N.Y. 1959).

25 Id. at 327. 
form. It is urged that a similar approach should be followed in infringement suits. It would seem that no valid policy reason could be advanced for granting less protection to a plaintiff "injured" by an infringement than to one "injured" by conduct violative of the antitrust laws.

The first part of the Schwartz opinion, dealing with the standing to sue problem created by the relationship between ASCAP and its composer and author members, is but one resolution in a series of cases dealing with that problem. ${ }^{26}$ The result in Schwartz, which tends to make the composer and ASCAP interdependent as far as standing to sue, is somewhat contrary to the general trend of these cases. The retained "interest" in a publisher who has transferred his public performance rights to ASCAP was recognized as early as 1924, in M. Witmark \& Sons v. Pastime Amusement Co.27 In Witmark the court decided that the transfer to ASCAP was merely a license and therefore the publisher plaintiff had standing to sue as the "copyright proprietor." 28 The result reached in Witmark was followed in Feist, Inc. v. Young 29 and in the recent case of Dorchester Music Corp. v. National Broadcasting Co. ${ }^{30}$ The theory used in the Feist case was that "even if the Copyright Act did not provide that such actions may be brought by the copyright proprietor" the suit could still be maintained since "plaintiff [publisher] is the principal and ASCAP is the agent ...." 31

A recognition of the similar interests of ASCAP and its members in infringement suits was contained in the Second Circuit's opinion in Buck v. Elm Lodge Inc.32 In the Buck case the court allowed ASCAP to sue for infringement of its public performance rights by joining the corporate owners of the copyrights, even though ASCAP alone was considered the real party in interest. The court declared that the "corporate plaintiffs were necessary parties merely because they hold their causes of action in trust for the society." 33 The ostensible basis for the court's decision was that "convenience would be ... promoted by uniting the causes of action, since any recovery of damages ... would go to the society." 34 In Widenski v. Shapiro, Bernstein \& Co.35 the most widely cited case in the series, the court cleared up any doubts engendered by Buck about the publisher's right to sue in his own name. The court

26 See Widenski v. Shapiro, Bernstein \& Co., 147 F.2d 909 (1st Cir. 1945); Dorchester Music Corp. v. National Broadcasting Co., 171 F. Supp. 580 (S.D. Cal. 1959); M. Witmark \& Sons v. Pastime Amusement Co., 298 Fed. 470 (E.D.S.C. 1924); Buck v. Elm Lodge, Inc., 83 F.2d 201 (2d Cir. 1936); Feist, Inc. v. Young, 138 F.2d 972 (7th Cir. 1943).

27 Supra note 26.

28 The formalistic reasoning employed here may be compared with the reasoning used in Schwartz v. Broadcast Music Inc., 180 F. Supp. 322 (S.D.N.Y. 1959).

29138 F.2d 972 (7th Cir. 1943).

30171 F. Supp. 580 (S. D. Cal. 1959).

33 Id. at 202.

31138 F.2d at 974.

34 Ibid.

3283 F.2d 201 (2d Cir. 1930).

35147 F.2d 909 (1st Cir. 1945). 
reasoned that "ASCAP [was] not an assignee but a licensee under rule of Waterman and so could not maintain a suit for infringement alone but could do so only by joining the copyright proprietor as plaintiff [citing the Buck case] and hence the defendant being fully protected from a second suit for the same infringement there is no necessity for joining ASCAP as a party plaintiff." 36

The convenient reconcilation effected in Widenski between the publisher's interest in protecting infringement of his composition and the defendant's inierest in preventing multiple suits is also evident in cases where the copyright propi:etor is made an involuntary plaintiff. 37 The most important recent copyright case where this joinder was allowed was Ilyin v. Avon Publications, Inc. ${ }^{38}$ In Ilyin the plaintiff was found to be an exclusive licensee and the court therefore looket at the case as one in which an exclusive licensee was suing an infringer and was rot able to do so because of an inability to join a foreign copyright owner. The court, however, would "not permit a wrong to remain unrighted," and therefore "the decree will be left open to enable plaintiff to request the copyright proprietor to join as a co-plaintiff. If such a request is refused the plaintiff may serve the copyright proprietor with a notice of suit and make it an involuntary plaintiff. Federal Rules of Civil Procedure rule 19(a), 28 U.S.C.A. This will afford the involuntary party full opportunity to rrotect its rights as well as protect the defendants from multiplicity of actions."'39

The protection afforded the plaintiff in Ilyin was based on the patent case of Independent Wireless Corp. v. RCA.40 In Independent Wireless the Supreme Court held that the patent owner holds the license in trust for the licensee, to the extent that he must allow the use of his name as.plaintiff in an infringement action brought by the licensee. The Court saw an obligation on the part of the patent owner to allow the use of his name and title to protect all lawful exclusive licensees against infringers; an obligation which overshadowed the fact that the plaintiff's name was being used without authority. 41

The facts of the case show that the Court in Independent Wireless seemed to be concerned about possible collusion between the patent owner and the defendant. Certainly, the possibility of collusion in future similar cases would

36 Id. at $910-11$.

37 Ilyin v. Avon Publications, Inc., 144 F. Supp. 368 (S.D.N.Y. 1950); Field v. True Comics, 89 F. Supp. 611 (S.D.N.Y. 1950); Hoffman v. Saintly Joy, Inc., 51 F. Supp. 779 (S.D.N.Y. 1943); L. C. Page \& Co. v. Fox Film Corp., 83 F.2d 196 (2d Cir. 1936).

38 Supra note 37.

39 Id. at 374-75. For a discussion of the effect of the involuntary plaintiff provision of Rule 19(a), see Clark, Code PLeading 360 n.55 (1947).

40269 U.S. 459 (1926). Although Independent Wireless Tel. Co. was decided before the rew federal rules were put into effect, Rule 19(a) would seem to be an incorporation of the independent Wireless holding.

41 Id. at 473. 
have been increased if the Court had reached an opposite conclusion. If the bribe offered to the patent owner were higher than the contemplated reward from his licensees' legitimate use, the temptation to the patent owner to refrain from suing is more than a theoretical possibility. The prevention of collusion could also be considered a compelling justification for the result which the court reached in Ilyin v. Avon. The Court in Independent Wireless, however, did not believe that it was merely protecting the licensee against manifest injustice but that it was protecting the patent owner and the defendant as well. It protected the patent owner in that "by a request to the patent owner to join as co-plaintiff, by notice of the suit after refusal and the making of the owner a co-plaintiff, he is given a full opportunity by taking part in the cause to protect himself...."42 Moreover, "if he [the patent owner] declines to take any part in the case, though he knows of its imminent pendency and of his obligation to join he will be bound by the decree which follows." 43 The defendant was protected in that the decree rendered in the case would save him from a multiplicity of suits. The copyright proprietor and the defendant in Ilyin $v$. Avon would seem to be no less worthy of receiving judicial protection of their interests.

The trust theory utilized in Independent Wireless, but not expressed in Ilyin v. Avon, was the theoretical basis for two cases, prior to Ilyin v. Avon, which allowed the involuntary joinder of a copyright proprietor. ${ }^{44}$ In $L$. C. Page \& Co. v. Fox Film Corp. 45 the owner of motion picture rights was allowed to join the copyright owner as a "nominal" party plaintiff because the owner was a limited trustee for the purpose of instituting infringement suits. In Hoffman v. Saintly Joy Inc. 46 the court, following Independent Wireless, reasoned that if the copyright owner had been without the jurisdiction it could have been requested to join, and if it did not join it could be made an involuntary plaintiff and thus bound by the court's adjudication. The trust theory enunciated in these early cases is at best a stop gap which creates more prob-

42 Id. at 474.

43 Id. at 473. The authority cited for this proposition by the court seems somewhat questionable, but the question would appear to be moot due to the sulsequent acceptance of Independent Wireless in the patent feld. See Holliday \%. Long, 18 F.R.D. 45 (E.D.N.C. 1955); Innis Spieden \& Co. v. Food Mach. Corp., 2 F.R.D. 261 (D. Del. 1942) (exclusive licensee allowed to intervene in suit by patent owner because if patent adjudged invalid exclusive licensee would be bound). In Holliday the court ruled that in an infringement action by the patent owner the exclusive licensee has an interest and should be joined in order to bring all proper parties before the court. The court reasoned that if the licensee were not joined and the plaintiff recovered against the defendant, the defendants might be subjected to a subsequent action for the same infringement.

44 Hoffman v. Saintly Joy, Inc., 51 F. Supp. 779 (S.D.N.Y. 1943); L. C. Page \& Co. v. Fox Film Corp., 83 F.2d 196 (2d Cir. 1930).

45 Supra note 44.

4651 F. Supp. 779 (S.D.N.Y. 1943) (dicta). 
lems than it solves. If the copyright owner is considered as suing on his licensee's behalf, complex questions concerning apportionment of the recovery are presented. The more explicit rationale used in Ilyin $v$. Avon, that the court is seeking to protect the interests of all the parties involved, is to be preferred to the highly fictional approach of calling the copyright owner the licensee's trustee for purposes of bringing an infringement suit. The Ilyin $v$. Avon rationale could easily be utilized to allow ASCAP to join involuntarily its publisher members in infringement suits maintained by ASCAP, although this type of joinder has not as yet been necessary.

In general, the utilization of the "involuntary plaintiff" in copyright cases would seem to accomplish in a circuitous way what an interest approach would accomplish directly. If the court asked whether or not the particular plaintiff before it was "in fact" injured, a copyright owner would not have standing to sue when he had divested himself of the very rights which he was seeking to enforce, regardless of his presence as plaintiff in an earlier infringement suit. The adoption of an "interest" or "direct injury" approach to standing to sue problems in the license area may appear to be an innovation at the price of certainty; yet it creates no more uncertainty than that entailed in the old assignment-license issue. In addition, this approach has the advantage of explicitly denoting what is now actually motivating the courts.

II

The cases discussed thus far have concerned themselves with giving the owner of less than the entire copyright his day in court. But standing to sue may also be a problem where the entire copyright has been transferred and something akin to a royalty interest retained. Although legal title to the copyright rests in one person and he has not transferred any part of it, it may be shown that he holds the title as trustee for a third party having the beneficial cwnership. 47 The owner of the equitable title has the ability to sue in his own rame. 48 The equitable title holder, however, must face a threshold jurisdictional problem which did not have to be faced by the licensee.

It appears clearly settled in patent litigation that a suit "without the owner of the patent as a plaintiff if maintainable would not be a suit [under the Federal Patent Statute and hence 'arising under' federal law] ... but only an action in equity based on the contract rights of the licensee under the license and a stranger's violation of them. There would be no jurisdiction in courts of the United States to entertain it unless by reason of diverse citizenship of the parties ... . "49 In copyright cases the court has jurisdiction of the "equitable" owner's infringement suit, because the primary and controlling purpose of the

47 Bail, The Law of Copyright and Literary Property 475 (1944).

48 See, e.g., Ted Browne Music Co. v. Fowler, 290 Fed. 751 (2d Cir. 1923); Manning v. Miller Music Corp., 174 F. Supp. 192 (S.D.N.Y. 1959).

49 Independent Wireless Co. v. RCA, 269 U.S. 459, 466-67 (1925). Compare Dell Mfg. Co. v. Goff, 125 F.2d 676 (6th Cir. 1942). 
suit is to enforce a right secured by the copyright laws even though incidentally it draws into question the validity and interpretation of a contract through which the plaintiff derives title.50 Once the facts of the case are determined "sufficient" to justify an allegation that the plaintiff is equitable owner, 51 the courts treat the equitable owner as a "copyright proprietor" within the meaning of the statute and permit him to maintain suit for infringement.52 The problem faced by plaintiffs is that they must be careful to make their suit one for infringement so that the court may have jurisdiction. In Harrington v. Mure, 53 a 1960 case, the plaintiff sought an assignment of an interest in the copyright and an accounting of a share of the proceeds, rather than relief for an alleged infringement. 54 The court held that the plaintiff's claim was not one "arising under" any act of Congress. It reasoned that the sources of obligations to assign and account were equitable doctrines relating to unjust enrichment, and hence the state court could grant the plaintiff the relief he sought. The court rejected the plaintiff's argument that it was drawing an untenable distinction between the wrongful acts of a co-author and the wrongful acts of a third party by saying this "technicality" was a direct result of the congressional plan with respect to copyright litigation. The result in Harrington, although seemingly "technical," is apparently a correct one and should be followed. The power to decide title claims in infringement suits is a type of "ancillary jurisdiction" and should be strictly limited. Congress did not reserve to the federal courts all questions of copyright title. Congress left a considerable residue of power to the state courts to pass on title questions, and if the equitable title holder is not seeking to enforce a right secured by the Copyright Act, there seems to be no valid reason for federal courts to entertain title questions.

The reconciliation between competing considerations afforded by the involuntary plaintiff approach in licensee cases may be accomplished in the equitable title cases by making the legal owner a defendant, even though he was not an infringer.55 In Manning v. Miller Music Corp.,56 the court held that, "since the plaintiff [equitable owner] had joined the 'record' owner as defend-

50 Wooster v. Crane, 147 Fed. 515 (8th Cir. 1906).

51 Southern Music Publishing Co. v. Walt Disney Prods., 73 F. Supp. 580 (S.D.N.Y. 1947). The precise issue before the court was whether the alleged equitable title holder's infringement claim was one "arising under" the copyright law or merely a common law cause of action for specific performance of a contract. The court held that since the plaintiff had sufficiently alleged facts showing it to be the equitable owner it had jurisdiction of the suit.

52 Manning v. Miller Music Corp., 174 F. Supp. 192 (S.D.N.Y. 1959), 7 U.C.L.A. L. REv. 520 (1960).

53186 F. Supp. 655 (S.D.N.Y. 1960).

${ }^{54}$ It would seem that under the facts of the case-a wrongful assignment of the copyright by a co-author-an infringement claim would not have been possible.

ss See Manning v. Miller Music Corp., 174 F. Supp. 192 (S.D.N.Y. 1959).

56 Supra note 55. 
ant and had alleged refusal on his part to sue," the plaintiff had standing to sue for infringement under the Copyright Act.57 The court recognized the plaintiff's interest as one "which requires protection as much as does the interest of a licensee." 58 The court declared that in the licensee cases what the courts sought to protect was the licensee's "right of direct exploitation of the portion of the copyrighted materjal which is the subject of his license." 59 Since the plaintiff in Manning was entitled to "participate in all proceeds from all forms of exploitation" his interest was even more deserving of protection. 60 If the plaintiffs had been denied "the right to compel the proprietor to assert causes of action for their benefit, their reserved rights of participation will be gravely impaired and their reserved rights of statutory renewal compromised."61 By the court's joining the unwilling proprietor, complete justice can be obtained in one suit and a multiplicity of suits avoided. Moreover, a plaintiff whose interest has "in fact" been injured will be protected.

A recent extension of the Manning case has strengthened the principle of avoiding multiple. litigation which was first enunciated there. In Whitney $v$. Ross Jungnickel Inc., 62 the copyright proprietor was joined as a defendant and was allowed to cross claim against the infringer defendant for the same relief sought by the plaintiffs. This extension is clearly warranted if the copyright proprietor's "interest" is not to be prejudiced in a suit where he has been joined as a defendant.

The theoretical basis for the Manning decision may be found in a line of cases following the celebrated decision in Wooster v. Crane. 63 Equitable title in Wooster was considered to be in the plaintiff by virtue of an agreement by which the defendant gave the plaintiff the exclusive right to publish her copyrighted book. The infringement charged by the plaintiff was that the defendant (copyright owner) had published certain copies of the book on her own. The manifest unfairness of denying the plaintiff standing to sue led the court to the conclusion that, where one who "has legal title is one of the infringers and occupies a position altogether hostile to the complainant" the plaintiffs right to sue in its own name "is plain in principle." 64 Ted Browne Music Co. v. Fowler ${ }^{65}$ and Bisel v. Ladner 66 firmly established the principle that the equitable owner was not a "mere licensee" and could sue in his own name where the legal title holder was the infringer.

The Manning case, however, is not a mere reaffirmation of the Wooster 57 Id. at 197.

58 Ibid.

62179 F. Supp. 751 (S.D.N.Y. 1960).

59 Ibid.

63147 Fed. 515 (8th Cir. 1906).

60 Ibid.

64 Id. at 518.

61 Ibid.

65290 Fed. 751 (2d Cir. 1923).

661 F.2d 436 (3d Cir. 1924). Accord. Henry Holt \& Co. v. Liggett \& Myers Tobacco Co., 23 F. Supp. 302 (E. D. Penn. 1938). 
principle. The legal title holder who was made a defendant in Manning was not an infringer, nor did the plaintiff in Manning have more than a royalty interest. The position of the equitable title holder, when the legal title holder was not an infringer, had not been clarified by prior case law. In Schellberg v. Empring$h a m, 67$ where the legal holder was made a "nominal" plaintiff, the equitable title holder had standing to sue even though the legal title holder "asks nothing, expects nothing and wants nothing for itself." 68 An effort, prior to Manning, to make the noninfringing legal title holder a defendant, however, had been denied. In Springfield v. Warner Bros. Pictures 69 an alleged equitable title holder had made the legal title holder a defendant because the copyright "owner" had refused to institute the suit. The court dismissed the suit, apparently on the basis that equitable title had not been shown. The plaintiff argued the applicability of Wooster $v$. Crane but the court was able to cavalierly dismiss this argument, ostensibly because the legal title holder in Springfield had not been an infringer. The court in Manning, however, was able to hurdle the argument that the legal title holder should not be made a defendant because he was not technically an infringer. The court used a trust analogy and stated that "It is well settled that a fiduciary who refuses to bring suit against a third party for the benefit of his cestui abuses his trust."70 Having already found that a fudiciary relationship existed between the legal and equitable title holders, it was but a short jump to say that the equitable owner may join his erring "trustee" as a defendant in a suit to maintain his rights. In Manning a composer-publisher relationship was considered a fiduciary one, because the composer's livelihood is based on a good faith attempt on the publisher's part to exploit the composition. 71 The protection of the holder of a royalty interest seems to be the key consideration in the equitable title cases; yet the trust theory used to protect these "equitable" owners has limited the protection available.

Establishing the necessary trust relationship appears to be the central problem in the equitable title cases. As the court declared in Bisel, legal title may be "held ... in trust for the true owner, and the question of true ownership is one of fact, dependent upon the circumstances of the case."72 The situation in

6736 F.2d 991 (S.D.N.Y. 1929). An earlier case, Witwer v. Harold Lloyd Corp., 46 F.2d 792 (S.D. Cal. 1930), indicated that joinder may not in fact be necessary where the legal title holder has only a nominal interest and the equitable owner is the real party in interest.

6336 F.2d at 993.

6951 F. Supp. 746 (S.D.N.Y. 1943).

70 Manning v. Miller Music Corp., 174 F. Supp. 192, 196 (S.D.N.Y. 1959).

71 The fiduciary relationship between a composer and his publisher cannot be extended so as to make the composer an indispensable party defendant where the publisher is sued for infringement of a third party's composition. Robbins Music Corp. v. Alamo Music Inc., 119 F. Supp. 29 (S.D.N.Y. 1954). For "it is hornbook law that an aggrieved party is not compelled to sue all tort feasors." Id. at 31 .

72 1 F.2d at 438. Cf. Cohan v. Richmond, 19 F. Supp. 771 (S.D.N.Y. 1937). 
which a trust is most often found is where a composer or author has transferred his copyright to a publisher; for, as was pointed out in Manning, the composer or author by this transaction becomes dependent upon the publisher for exploitation of his work. ${ }^{73} \mathrm{His}$ economic livelihood becomes dependent upon the effort expended by his publisher. The wording of the agreement by which the copyright is transferred is normally the key factor upon which the existence of a trust is made to depend. The presumption indulged in by the courts is that in the absence of proof to the contrary it must be presumed that the plaintiff (author or composer) transferred his work without reservation to the publisher. ${ }^{74}$ This presumption may certainly be rebutted by the creation of an express trust in favor of the composer or author. 75 In the absence of an express trust a clause reserving the right to sue is probably necessary. In Manning a clause in the transfer agreement provided that the plaintiffs "reserved and retained the right to institute [this] action in the event that their publisher does not do so."76 An express promise on the part of the publisher to defend the copyright in cases of infringements has also been sufficient for the court to declare that a trust existed. 77 Merely a "reversionary" interest in the copyright at the time of the infringement, however, has not been sufficient to constitute the composer or author an equitable title holder. 78

In two other situations the "equitable title" or "trust" fiction has also been indulged in so as to give a person who would be substantially harmed standing to sue. One who contracts to purchase a copyright at a definite time in the future acquires by the contract the equitable title to the copyright and the right to sue infringers. $79 \mathrm{It}$ is also clearly established that the co-author of a work may sue in his own name, regardless of whether the copyright title was acquired by another co-author. ${ }^{80}$ The plaintiffs' vulnerability is so manifest in these situations that the courts could not fairly deny them protection.

The concep: of equitable title, although normally used affirmatively to establish standing to sue, may be used defensively. The defendant in a suit brought by the legal title holder may assert equitable title in a third person or in himself and thereby defeat the legal holder's infringement claim. ${ }^{81}$ Thus, the

73 See Dam y. Kirk La Shelle Co., 175 Fed. 902 (2d Cir. 1910).

${ }^{74}$ Alexander v. Irving Trust Co., 132 F. Supp. 364 (S.D.N.Y. 1955).

75 Schellberg v. Empringham, 36 F.2d 991 (S.D.N.Y. 1929).

76174 F. Suro, at 194.

77 Wooster v. Crane, 147 Fed. 515 (8th Cir. 1906).

78 Kriger v. McFadden Publications, 43 F. Supp. 170 (S.D.N.Y. 1941).

79 Historical ?ublishing Co. v. Jones Bros. Publishing Co., 231 Fed. 638 (1916).

${ }^{80}$ See, e.g., $!$ larks Music Corp. v. Jerry Vog i Music Co., 140 F.2d 266 (1944). The double liability froblem inherent in ca. es of this ty pe has been solved by allowing the plaintiff to make the co-author who holds : he legal tite a defendant.

${ }^{81}$ See Harms \& Francis v. Stern, ..20 Fed. 42 (2d Cir. 1915); Press Publishing Co. v. Falk, 59 Fed. 324 (S.D.N.Y. 1894). 
use of equitable title as a defense has somewhat alleviated the double liability problem in the equitable title cases. 82

The trust theory advanced in the equitable title cases and in the licensee cases appears to be merely a judicial tool utilized to protect parties who "in fact" were injured. The inherent problem of donble liability is solved through the use of an involuntary plaintiff theory in the license cases and by joining the "record" holder as a defendant in the equitable title cases. Although statutory "divisibility" or the adoption of an "interest" approach might result in the abandonment of the trust concept and the involuntary plaintiff theory in the licensee cases, 83 neither of these solutions would entirely resolve the problem of the author or composer who transferred the entire copyright and merely retained a royalty interest. The actual dependence of the royalty interest holder upon the publisher makes the trust concept a good deal more palatable in the equitable title area than in the license area. Economic realities dictate that the composer should not attempt independent promotion of his composition. Something akin to a "trust" relationship has in fact been created where an author or composer's livelihood depends on the exploitation of his composition by a publisher. In addition the "interest" approach does not work as well where only a royalty interest is retained, since admittedly the legal title holder has more than a nominal interest. Since a trust concept in the equitable title cases and an interest approach in the licensee cases push in the same direction-protection of a substantial interest without double liability-their respective use where applicable would appear desirable.

82 See cases cited note 81 supra.

83 None of the various bills proposing divisibility have suggested that the royalty right be considered a several and distinct interest. 